\title{
Measuring medicine prices in Peru: validation of key aspects of WHO/HAl survey methodology
}

\author{
Jeanne M. Madden, ${ }^{1}$ Edson Meza, ${ }^{2}$ Margaret Ewen, ${ }^{3}$ Richard O. Laing, ${ }^{4}$ \\ Peter Stephens, ${ }^{5}$ and Dennis Ross-Degnan ${ }^{1}$
}

Suggested citation Madden JM, Meza E, Ewen M, Laing RO, Stephens P, Ross-Degnan D. Measuring medicine prices in Peru: validation of key aspects of WHO/HAI survey methodology. Rev Panam Salud Publica. 2010;27(4):291-9.

\begin{abstract}
Objectives. To assess the possibility of bias due to the limited target list and geographic sampling of the World Health Organization (WHO)/Health Action International (HAI) Medicine Prices and Availability survey used in more than 70 rapid sample surveys since 2001.

Methods. A survey was conducted in Peru in 2005 using an expanded sample of medicine outlets, including remote areas. Comprehensive data were gathered on medicines in three therapeutic classes to assess the adequacy of WHO/HAI's target medicines list and the focus on only two product versions. WHO/HAI median retail prices were compared with average wholesale prices from global pharmaceutical sales data supplier IMS Health.

Results. No significant differences were found in overall availability or prices of target list medicines by retail location. The comprehensive survey of angiotensin-converting enzyme inhibitor, anti-diabetic, and anti-ulcer products revealed that some treatments not on the target list were costlier for patients and more likely to be unavailable, particularly in remote areas. WHO/HAI retail prices and IMS wholesale prices were strongly correlated for higher priced products, and weakly correlated for lower priced products (which had higher estimated retailer markups).

Conclusions. The WHO/HAI survey approach strikes an appropriate balance between modest research costs and optimal information for policy. Focusing on commonly used medicines yields sufficient and valid results. Surveyors elsewhere should consider the limits of the survey data as well as any local circumstances, such as scarcity, that may call for extra field efforts.
\end{abstract}

Key words Drug price; validation studies; health care surveys; pharmacies; sampling studies; Peru.

1 Department of Population Medicine, Harvard Medical School and Harvard Pilgrim Health Care Institute, Boston, Massachusetts, United States of America. Send correspondence to: Jeanne M. Madden, Department of Population Medicine, Harvard Medical School and Harvard Pilgrim Health Care Institute, 133 Brookline Avenue, 6th Floor, Boston, Massachusetts 02215, USA; e-mail: jeanne madden@hphc.org

2 Acción Internacional para la Salud Latinoamérica y Caribe, Lima, Peru.

3 Global Projects, Health Action International, Netherlands.

4 Medicine Information and Evidence for Policy, Department of Essential Medicines and Pharma-
Since 2001, more than 70 rapid sample surveys have been conducted in low-tomiddle income countries using a methodology developed by the World Health Organization and Health Action International for the WHO/HAI Project on Medicine Prices and Availability. The surveys

ceutical Policies, World Health Organization,

Geneva, Switzerland.

5 IMS Health, London, United Kingdom. describe pharmaceutical prices and pricing problems in support of advocacy for policy reforms to increase access to essential medicines $(1,2)$. These national surveys report on availability of medications in public and private sector pharmacies and compare availability and prices among product versions (originator brands and their generic equivalents), sectors, and regions. Several international synthesis reports have examined the wide 
variation among results from different countries (3-5).

The WHO/HAI survey methodology relies on data collectors visiting a sample of at least 30 medicine outlets per sector (public, private retail, mission, or other nongovernmental organization) to obtain prices for a defined basket of up to 50 medicines. The sample of regions and outlets surveyed strikes a balance between representativeness and practicality of execution using limited resources, as in other rapid sample methodologies $(6,7)$. However, such designs involving only small numbers of purposively selected facilities and case types may mask potential biases.

To investigate the extent of these biases, a survey was carried out in Peru in 2005 using samples of regions and outlets expanded in specific ways. This special validation survey sought to determine if 1) medicine availability and price differed in more remote areas excluded from standard WHO/HAI surveys by design, 2) medicines on the core list reflected overall medicine availability and prices, 3) limiting data to the originator brand and the lowest priced generic (LPG) version accurately captured overall prices for a given medicine, and 4) retail prices from WHO/HAI surveys agreed with independent estimates of price.

\section{MATERIALS AND METHODS}

\section{Standard WHO/HAI survey approach}

At the time of the current study, the standard WHO/HAI Medicine Prices and Availability survey sample for Peru comprised four geographic regions-the main metropolitan region and three others within a day's journey of it (since then, the survey design has been modified to include two additional regions). In each region, the standard sample includes 10 medicine outlets (five public health facilities and five private retail pharmacies). The five public health facilities include the public pharmacy at the main [regional] public hospital and the medicine outlets at four randomly selected primary care facilities within three hours of the main hospital. The five private facilities include one retail pharmacy for each public health facility, selected by proximity. An additional outlet is added if fewer than $50 \%$ of target medicines are found in a given outlet. Local teams select the target medicines to be surveyed, including 30 on a core list specified by the WHO/HAI project, plus up to 20 locally important medicines. For each medicine, at each outlet, teams collect data on two types of products: originator brands, and their LPG equivalents-non-originator products marketed under International Nonproprietary Names (INNs) or other brands.

Availability is measured by the physical presence of a product in an outlet at the time of survey. Surveys report the percentage availability of both originator brands and generics. Median percentage availability is then calculated across all medicines surveyed.

The price per unit (e.g., tablet or milliliter) is recorded in local currency for each medicine in a recommended package size. The median unit prices for the originator brands and LPGs across outlets are expressed as ratios over international reference procurement prices for bulk generics (8) using the U.S. dollar exchange rate on the first day of data collection. The resulting median price ratio (MPR) is a standardized measure useful for comparisons among medicines or between surveys. The surveys also report "brand premiums" (the ratio of median originator brand and LPG prices), when calculable. Medicine affordability is determined by comparing local wages with treatment costs per month (for chronic illness) or episode (for acute illness), based on standard treatment guidelines and median unit prices.

\section{Approach to validation in Peru}

In 2005, a specially expanded WHO/ HAI Medicine Prices and Availability survey was conducted in Peru to assess potential biases in the standard sampling methodology due to 1) the systematic exclusion of remote geographic areas and pharmacies, and 2) the restriction of data collection to originator brand and LPG products. In addition, retail prices from the survey were compared with independently obtained wholesale prices within one commonly used therapeutic class.

Peru, the setting for the validation study, is a mid-sized, ethnically and geographically diverse South American country with a population of 28 million and a per capita income of US\$ 3000 , with $30 \%$ of the population living on less than US \$2 per day (9). At the time of the study, the pharmaceutical sector was characterized by weak government regulation and low barriers to new product entry. Consequently, there was a wide variety of medicines on the market and a rich, complex environment for examining prices and availability.

The expanded survey included two additional areas that were more remote than those covered in the standard survey (i.e., beyond a day's journey from Lima), resulting in six surveyed regions out of the 25 total administrative regions in Peru. In addition, in each of the six regions, the validation sample added seven medicine outlets that would have been excluded under the standard survey design: two public health facilities and two nearby private pharmacies more than three hours away from the main public hospital, plus three private pharmacies far from the reference public health facilities but within their catchment areas. The final sample consisted of 52 public sector medicine outlets and 96 private pharmacies.

The WHO/HAI survey target medicines for Peru included the 30 items from the $2005 \mathrm{WHO} / \mathrm{HAI}$ core list plus eight supplemental medicines important in Peru (determined locally). Analyses assessing the differences in results due to the geographic expansion of the standard sample were based on this list of 38 medicines (see Table 1). In addition, surveyors collected prices on all available medicines-including all product versions - in three therapeutic classes (angiotensinconverting enzyme (ACE) inhibitors used in the treatment of hypertension, antiulcerants, and oral diabetes medications) to assess possible biases caused by the WHO/HAI restriction of data collection to originator brand and LPG product versions of core list medicines.

Finally, average wholesale prices in Peru at the time of the survey were obtained for specific ACE inhibitor products, from the market survey of global pharmaceutical sales data supplier IMS Health (10), to compare results from the WHO/HAI survey methodology to data regarded as the gold standard for pharmaceutical market research (11).

\section{Analyses}

Median availability of the 38 standard survey medicines was compared among 1) private pharmacies located in urban areas ( $\leq 30$ minutes from a town with a population $>50000 ; n=43$ ), semi-urban 
TABLE 1. List of 38 target medicines surveyed in Peru, 2005, based upon the standard World Health Organization/Health Action International Medicine Prices and Availability methodology

\begin{tabular}{|c|c|}
\hline Medicine (generic name) ${ }^{a}$ & Common indication \\
\hline Aciclovir, $200 \mathrm{mg}$ tablet & Antiviral \\
\hline Amitriptyline, $25 \mathrm{mg}$ tablet & Antidepressant \\
\hline Amoxicillin, $250 \mathrm{mg}$ tablet & Antibacterial \\
\hline Amoxicillin, ${ }^{\mathrm{b}} 500 \mathrm{mg}$ tablet & Antibacterial \\
\hline Artesunate, $100 \mathrm{mg}$ tablet & Antimalarial \\
\hline Atenolol, $50 \mathrm{mg}$ tablet & Antihypertensive \\
\hline Beclometasone, $0.05 \mathrm{mg} /$ dose inhaler & Anti-asthmatic \\
\hline Captopril, $25 \mathrm{mg}$ tablet & Antihypertensive \\
\hline Carbamazepine, $200 \mathrm{mg}$ tablet & Antiepileptic \\
\hline Ceftriaxone, $1 \mathrm{~g} / \mathrm{vial}$ injectable & Antibacterial \\
\hline Ciprofloxacin, 500 mg tablet & Antibacterial \\
\hline Chlorphenamine,$^{\mathrm{b}} 4 \mathrm{mg}$ tablet & Antihistamine \\
\hline Clotrimazole, ${ }^{\mathrm{b}} 500 \mathrm{mg}$ suppository & Antifungal \\
\hline Co-trimoxazole, ${ }^{\mathrm{b}} 160 / 800 \mathrm{mg}$ tablet & Antibacterial \\
\hline Co-trimoxazole, $8+40 \mathrm{mg} / \mathrm{ml}$ suspension & Antibacterial \\
\hline Diazepam, 5 mg tablet & Anxiolytic \\
\hline Diclofenac, $25 \mathrm{mg}$ tablet & Anti-inflammatory \\
\hline Erythromycin, ${ }^{\mathrm{b}} 500 \mathrm{mg}$ tablet & Antibacterial \\
\hline Fluconazole, ${ }^{\text {b }} 150 \mathrm{mg}$ tablet & Antifungal \\
\hline Fluconazole, 200 mg tablet & Antifungal \\
\hline Fluoxetine, 20 mg tablet & Antidepressant \\
\hline Fluphenazine, $25 \mathrm{mg} / \mathrm{ml}$ injectable & Antipsychotic \\
\hline Glibenclamide, $5 \mathrm{mg}$ tablet & Antidiabetic \\
\hline Hydrochlorothiazide, $25 \mathrm{mg}$ tablet & Antihypertensive \\
\hline Ibuprofen, ${ }^{\mathrm{b}} 400 \mathrm{mg}$ tablet & Anti-inflammatory \\
\hline Indinavir, 400 mg tablet & Antiviral \\
\hline Losartan, 50 mg tablet & Antihypertensive \\
\hline Lovastatin, $20 \mathrm{mg}$ tablet & Serum-lipid reducing \\
\hline Metformin, $500 \mathrm{mg}$ tablet & Antidiabetic \\
\hline Metronidazole, ${ }^{\mathrm{b}} 500 \mathrm{mg}$ tablet & Antibacterial \\
\hline Nevirapine, 200 mg tablet & Antiviral \\
\hline Nifedipine Retard, $20 \mathrm{mg}$ tablet & Antihypertensive \\
\hline Omeprazole, 20 mg tablet & Anti-ulcerant \\
\hline Phenytoin, 100 mg tablet & Antiepileptic \\
\hline Ranitidine, $150 \mathrm{mg}$ tablet & Anti-ulcerant \\
\hline Salbutamol, $0.1 \mathrm{mg} / \mathrm{dose}$ inhaler & Anti-asthmatic \\
\hline Sulfadoxine-pyrimethamine, $500+25 \mathrm{mg}$ tablet & Antimalarial \\
\hline Zidovudine, $100 \mathrm{mg}$ tablet & Antiviral \\
\hline
\end{tabular}

areas ( $>30$ minutes but $\leq 2$ hours; $n=23$ ), and rural areas ( $>2$ hours; $n=30$ ); 2 ) the 18 private pharmacies nearest and the 21 farthest from the reference public facilities; and, in a separate analysis, 3) the six administrative regions. Nonparametric 95\% confidence intervals (CIs) were constructed and compared for each median, using order statistics (12). It was not possible to calculate exact $p$-values for the differences across medians, as they were computed using order statistics. However, non-overlapping CIs indicated where differences were significant. Prices were compared by location using the median MPR for medicines that were available at three or more outlets in every subset analyzed.

These analyses were repeated for medicine availability, patient prices, and procurement prices in the public sector. In Peru, in 2005, standard patient costs for medicines in public facilities were based on an official price list plus a fixed $25 \%$ facility profit designed to ensure access. However, local pricing practices were variable. The procurement prices used in the study were collected from regional administrators' most recent purchases.

All medicines in the three expanded therapeutic classes were qualitatively compared in terms of the number of public and private outlets that had them in stock, the number of different products and product versions found, and median unit prices. No statistical tests were conducted because of the small numbers of medicines being compared. Medicine price data, originally in Peru- vian nuevos soles, were converted to U.S. dollars based on the September 2005 exchange rate (13). The authors compared the unit prices, monthly treatment costs, brand premiums, and median MPRs for 1) core list and non-core list medicines and 2) the results measured in the standard WHO/HAI survey and those obtainable only when surveying an expanded sample of products.

Retail prices from the standard survey were matched to IMS average wholesale prices measured independently in the same period for 27 ACE inhibitor products and arrayed in a scatter plot. Correlations and estimated retailer markups were calculated for higher- and lowerpriced products.

Further details of the methods used and results obtained are available on the WHO/HAI project Web site $(2,14,15)$.

\section{RESULTS}

\section{Medicine availability by geographic location}

Table 2 compares availability of the 38 standard survey medicines by remoteness of both private retail and public outlets. The median availability of a generic product was similar in urban, semiurban, and rural private outlets $(63 \%$, $57 \%$, and $62 \%$, respectively; not significant), and in retail outlets near (64\%) and far from $(62 \%)$ the reference public health facilities. Median availability of originator brand products was low in private retail pharmacies and was not associated with remoteness of location. Comparisons of availability among results for the six administrative regions also indicated no significant differences (15).

In Peru's public sector, median availability of the 38 target medicines was nearly identical in urban $(57 \%)$, semiurban (56\%), and rural (57\%) clinics. One of the two additional remote regions studied had a lower public sector median availability (29\% versus $45-71 \%$ for the remaining five regions). However, because the CIs were quite wide, this difference was not statistically significant (15).

\section{Medicine prices by geographic location}

Private sector prices in Peru for medicines on the standard WHO/HAI survey list, expressed as MPRs in relation to international reference prices, are also pre- 
TABLE 2. Median availability and median of MPR ${ }^{a}$ for lowest priced generics (LPGs) and originator brands (OBs) of target medicines $^{b}$ available at different types of medicine outlets, ${ }^{c}$ WHO/HAI Medicine Prices and Availability survey validation, Peru, 2005

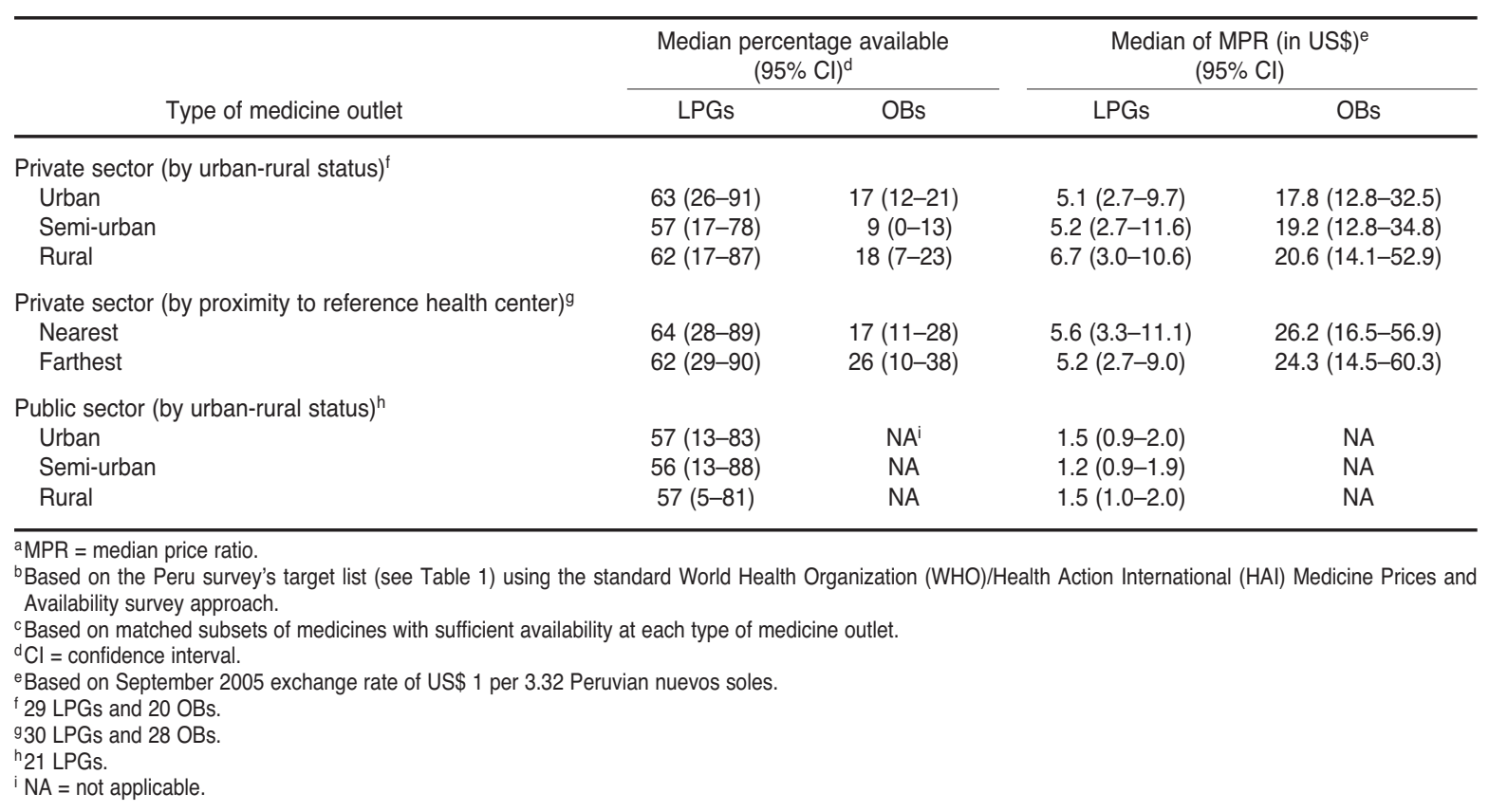

sented in Table 2. Comparing matched available products, the median MPRs for both originator brand and LPG products were slightly but nonsignificantly higher in rural versus urban areas, while those in semi-urban areas fell between the two. Median MPRs were also slightly higher in outlets nearer to public health facilities, although differences were again nonsignificant. There were also no significant differences in private sector prices across the six administrative regions analyzed in the study (15).

The median public sector patient MPR for the 21 medicines with sufficient price data was 1.2 for semi-urban clinics and 1.5 for both urban and rural clinics, with no significant differences. One region (within a day's travel from the capital and thus part of the standard sample) had a higher median MPR across 18 comparable medicines than the other five regions (2.6, versus a range of 1.1 to 1.4 ); this MPR was significantly higher than that found in the region with the lowest prices. Median MPRs for public procurement prices based on 12 standard survey medicines were very similar across regions (range 0.9 to 1.2; not significant).

\section{Availability of different product versions and therapies}

Table 3 presents data on private sector availability in the three expanded thera- peutic classes. There were important differences in the likelihood of finding each medicine and in the number of distinct products available at retail outlets. For example, captopril was found in every retail outlet surveyed, and 19 distinct captopril products were identified, along with 40 omeprazole products. In contrast, throughout the survey area, only the originator brand of fosinopril and two famotidine products were found, and each of the two medicines was only available at a single outlet (representing $1 \%$ of all outlets). The five medicines on the WHO/HAI core list (Table 3) were more likely than other medicines to be in stock and to have competing products available. However, two medicines not on the core list, enalapril and lansoprazole, were also widely available, in many different products, whereas 500-mg metformin, which was on the core list, was not widely available.

In general, data from the three expanded therapeutic categories did not suggest price differences by remoteness of location (15), although retail availability and product choice appeared higher in urban areas. For example, 21\% of urban outlets had $\geq 20$ distinct products available in the three therapeutic categories combined, whereas only $7 \%$ of rural outlets and no semi-urban outlets stocked this many products.
In the public sector (Table 4), four of the five WHO/HAI core list medicines in these therapeutic categories were found in $63 \%$ to $87 \%$ of facilities; of the non-core list medicines, only enalapril was found $(48 \%)$.

\section{Range in prices across therapeutic class}

The WHO/HAI survey methodology emphasizes originator brand and LPG prices. However, these benchmarks may not reflect the full range of prices across a medicine's therapeutic class. The median prices for the wider range of products covered in the expanded survey (converted from the local currency, nuevos soles, to U.S. dollars) are presented in Table 3. WHO's defined daily doses (DDDs) (16) are included to provide context for determining actual treatment costs.

Large variations in price were found for individual medicines and within therapeutic classes. For example, originator brand enalapril was typically $>16$ times the price of its LPG equivalent. As per the assumptions of the WHO/HAI approach, originator brands, when found, were always priced higher than other product versions. In most cases, the median LPG price was close to that of INN generic versions. For medicines with no INN generic, the LPG median price was 
TABLE 3. Private sector availability and median unit prices of all angiotensin-converting enzyme (ACE) inhibitors, anti-ulcerants, and anti-diabetic agents found in Peru, WHO/HAl ${ }^{\mathrm{a}}$ Medicine Prices and Availability survey validation, 2005

\begin{tabular}{|c|c|c|c|c|c|c|c|c|c|}
\hline \multirow[b]{3}{*}{ Medicine (generic name) } & \multicolumn{4}{|c|}{ Product availability } & \multicolumn{4}{|c|}{$\begin{array}{l}\text { Median unit price (in US\$) } \\
\text { within market category }\end{array}$} & \multirow[b]{3}{*}{$\begin{array}{l}\text { WHO } \\
\text { DDD }^{\mathrm{e}}\end{array}$} \\
\hline & \multicolumn{3}{|c|}{$\begin{array}{l}\text { Number of distinct } \\
\text { products found }\end{array}$} & \multirow{2}{*}{$\begin{array}{l}\text { Proportion } \\
\text { of outlets } \\
\text { with any } \\
\text { product } \\
(\%)\end{array}$} & \multirow{2}{*}{$\begin{array}{c}\text { Across } \\
\text { outlets } \\
\text { Lowest } \\
\text { priced } \\
\text { generics } \\
\text { (LPGs) }\end{array}$} & \multicolumn{3}{|c|}{$\begin{array}{l}\text { Across all observations } \\
\text { in market category }\end{array}$} & \\
\hline & $\begin{array}{c}\mathrm{INN}^{\mathrm{C}} \\
\text { generics }\end{array}$ & $\begin{array}{l}\text { Branded } \\
\text { generics }\end{array}$ & $\begin{array}{c}\text { Originator } \\
\text { brands }\end{array}$ & & & $\begin{array}{c}\text { INN } \\
\text { generics }\end{array}$ & $\begin{array}{l}\text { Branded } \\
\text { generics }\end{array}$ & $\begin{array}{l}\text { Originator } \\
\text { brands }\end{array}$ & \\
\hline Enalapril, 10 mg tablet & 14 & 7 & 1 & 83 & 0.06 & 0.06 & 0.54 & 0.98 & 1 \\
\hline Fosinopril, $10 \mathrm{mg}$ tablet & 0 & 0 & 1 & 1 & & & & 1.37 & 1.5 \\
\hline Lisinopril, 10 mg tablet & 0 & 3 & 1 & 10 & 0.67 & & 0.67 & 1.01 & 1 \\
\hline Quinapril, $10 \mathrm{mg}$ tablet & 0 & 0 & 1 & 10 & & & & 1.47 & 1.5 \\
\hline \multicolumn{10}{|l|}{ Anti-ulcerants } \\
\hline Cimetidine, $400 \mathrm{mg}$ tablet & 0 & 1 & 0 & 4 & 0.40 & & 0.40 & & 2 \\
\hline Ranitidine ${ }^{\dagger}{ }^{150} \mathrm{mg}$ tablet & 18 & 7 & 1 & 85 & 0.08 & 0.08 & 0.21 & 0.54 & 2 \\
\hline \multicolumn{10}{|l|}{ Antidiabetic agents } \\
\hline Chlorpropamide, $250 \mathrm{mg}$ tablet & 0 & 0 & 1 & 23 & & & & 0.30 & 1.5 \\
\hline Glibenclamide, ${ }^{\dagger} 5 \mathrm{mg}$ tablet & 9 & 3 & 0 & 88 & 0.06 & 0.06 & 0.24 & & 2 \\
\hline Gliclazide, $80 \mathrm{mg}$ tablet & 0 & 0 & 1 & 6 & & & & 0.49 & 2 \\
\hline Glimepiride, $4 \mathrm{mg}$ tablet & 0 & 1 & 1 & 18 & 0.96 & & 0.96 & 1.25 & 0.5 \\
\hline Glipizide, 5 mg tablet & 0 & 1 & 0 & 2 & 0.27 & & 0.27 & & 2 \\
\hline Metformin, ${ }^{\dagger} 500 \mathrm{mg}$ tablet & 1 & 2 & 1 & 19 & 0.17 & 0.15 & 0.19 & 0.24 & 4 \\
\hline Pioglitazone, $30 \mathrm{mg}$ tablet & 0 & 1 & 1 & 5 & 1.75 & & 1.75 & 3.13 & 1 \\
\hline Rosiglitazone, $4 \mathrm{mg}$ tablet & 0 & 1 & 1 & 4 & 1.23 & & 1.23 & 2.40 & 1.5 \\
\hline
\end{tabular}

a World Health Organization/Health Action International.

${ }^{b}$ Data collection was limited to the most commonly used strength of each survey medicine in tablet or capsule form. The total number of observations across the 96 private retail outlets for each individually marketed product ranged from 1 to 32 , with a median of 10 . Individual outlets may have contributed more than one INN generic observation or one branded generic observation, but no more than one price observation for the LPG in the retail outlet and for the originator brand. The total number of distinct products in a therapeutic class per outlet ranged from 1 to 21 for ACE inhibitors and from 1 to 40 for anti-ulcerants. Twelve outlets had no oral anti-diabetic agents, whereas the maximum number was 16 products in a single outlet.

${ }^{\mathrm{C}} \mathrm{INN}=$ International Nonproprietary Name.

'Based on September 2005 exchange rate of US\$ 1 per 3.32 Peruvian nuevos soles.

e Defined daily dose (number of tablets typically prescribed for one day of use) (16).

${ }^{f}$ WHO/HAl core list medicine in 2005.

typically close to that of branded generic versions.

For those products for which an originator brand is rarely found, the standard WHO/HAI methodology could fail to estimate the higher end of market prices. For example, Figure 1 shows price observations for the core medicine ranitidine among private retail outlets. The standard WHO/HAI statisticsmedian LPG price (US\$ 0.08) and median originator brand price (US\$ 0.54) appropriately summarize the range. However, because the originator brand was found in only $10 \%$ of the outlets that would have been included in a standard sample, this would result in too few originator brand prices to yield an estimate (four observations are required). The prices and availability of mid-priced branded generics, more widely available in Peru than the originator brands, are not captured in the standard survey. Similar patterns were observed for the other four core list medicines in the three expanded therapeutic classes (15).

In Peru, originator brand products were never found in the public sector, and branded generics appeared only occasionally. The standard WHO/HAI method captured the full range of public sector patient prices because public medicine outlets generally stock only one product per medicine and therefore the price collected for the LPG is the only price. The median prices for the LPGs of the five surveyed medicines that were available in the public sector (Table 4) were $40 \%$ to $91 \%$ lower than the corresponding private sector LPG median prices.

\section{Treatment costs within therapeutic class}

Figure 2 presents median monthly treatment costs using DDDs for INN generics, branded generics, and originator brands in the three expanded therapeutic classes. Median treatment costs for LPGs are not presented but in nearly all cases were close to those for the INN generics or the branded generics (when INN generics were not available).

WHO/HAI core list therapies did not represent the full range of affordability in the medicines market for the three therapeutic classes. Several originator brand ACE inhibitor and anti-diabetic treatments were substantially more costly than comparable core list products. Because INN generic products were more likely to be found on the market for core 
TABLE 4. Public sector availability and median unit prices of angiotensin-converting enzyme (ACE) inhibitors, anti-ulcerants, and antidiabetic agents in Peru, WHO/HAl ${ }^{\mathrm{a}}$ Medicine Prices and Availability survey validation, $2005^{\text {b }}$

\begin{tabular}{|c|c|c|c|c|}
\hline Medicine (generic name) & $\begin{array}{l}\text { Number of } \\
\text { distinct generic } \\
\text { products found }\end{array}$ & $\begin{array}{l}\text { Proportion of } \\
\text { facilities with } \\
\text { any product } \\
(\%)\end{array}$ & $\begin{array}{l}\text { Median price of } \\
\text { lowest priced } \\
\text { generics (LPGs) } \\
\text { across facilities } \\
\text { (in US\$) }\end{array}$ & $\begin{array}{l}\text { Median } \\
\text { procurement } \\
\text { price across } \\
\text { regions } \\
\text { (in US\$) }^{\mathrm{C}}\end{array}$ \\
\hline Captopril, ${ }^{\mathrm{d}} 25 \mathrm{mg}$ tablet & 11 & 87 & 0.006 & 0.006 \\
\hline Enalapril, $10 \mathrm{mg}$ tablet & 7 & 48 & 0.012 & 0.008 \\
\hline Omeprazole, ${ }^{\mathrm{d}} 20 \mathrm{mg}$ tablet & 4 & 63 & 0.045 & 0.031 \\
\hline Ranitidine, ${ }^{\mathrm{d}} 150 \mathrm{mg}$ tablet & 6 & 63 & 0.045 & 0.029 \\
\hline Glibenclamide, ${ }^{\mathrm{d}} 5 \mathrm{mg}$ tablet & 2 & 63 & 0.006 & 0.006 \\
\hline
\end{tabular}

aworld Health Organization/Health Action International.

b The five medicines listed in the table represent those simultaneously on Peru's Essential Medicines List (EML) and among the medicines in the three therapeutic categories specially expanded for the Peru validation study. Peru study medicines not on Peru's EML were not found in any surveyed public health facilities, as per national policy. Metformin was an unusual case in that $800 \mathrm{mg}$ tablets were on the EML but not available due to supply problems and therefore excluded from the study. Metformin $500 \mathrm{mg}$ tablets were on the $\mathrm{WHO} / \mathrm{HAl}$ core list and surveyed and found in the private sector.

'Based on September 2005 exchange rate of US $\$ 1$ per 3.32 Peruvian nuevos soles.

${ }^{\mathrm{d}} \mathrm{WHO} / \mathrm{HAl}$ core list medicine in 2005 . list versus non-core list therapies, an analysis of costs based on core list LPG prices may overestimate the affordability of a specific therapeutic class. For the same reason, WHO/HAI brand premium ratios may be higher for core list medicines than for alternative therapies. The average brand premium among four core list medicines in Peru's expanded therapeutic classes was 7.2 (median 7.1), whereas among seven non-core medicines the average brand premium was 3.5 (median 1.7).

Public sector medicine outlets typically stock only a single generic version of medicines on the national Essential Medicines List (EML). Consequently, comparisons between alternative treatments in the public sector are only occasionally possible in standard WHO/HAI surveys, and brand premium calculations are rare.

\section{WHO/HAI survey prices versus IMS prices}

Median retail prices at private pharmacies were compared between 27 ACE inhibitor products from Peru's expanded WHO/HAI survey and average whole-
FIGURE 1. Range and frequencies of prices for ranitidine in 96 private pharmacies, by market category, WHO/HAI Medicine Prices and Availability survey validation, Peru, 2005

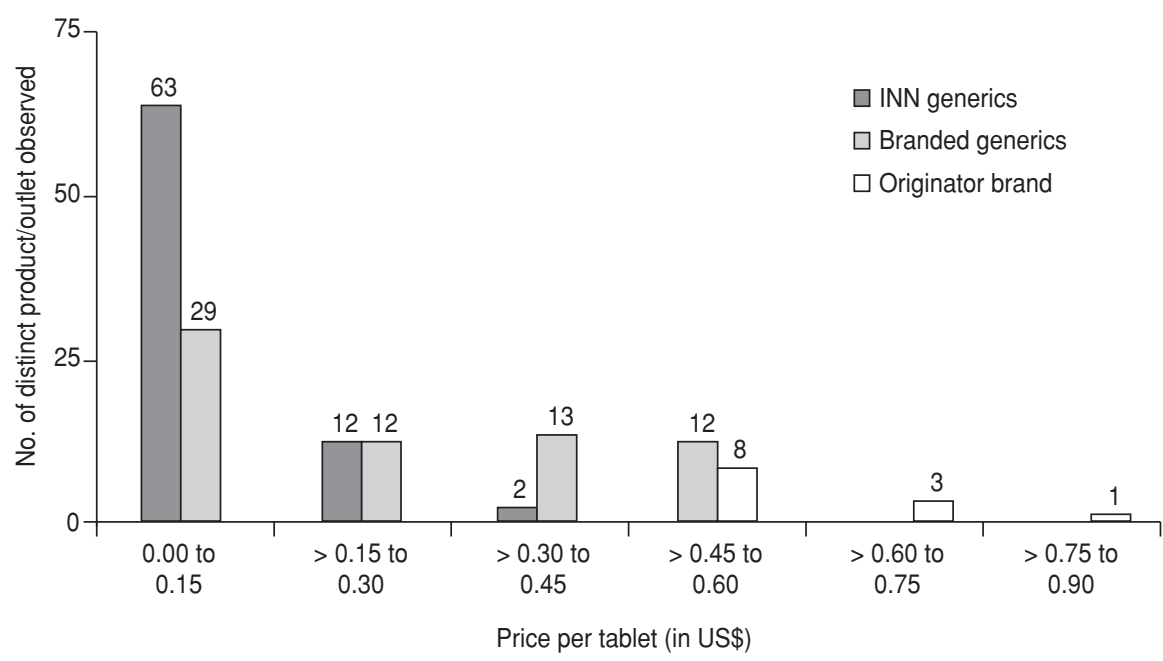

a Each observation represents the price of a distinct product found in a distinct private outlet.

${ }^{\mathrm{b}} \mathrm{WHO}=$ World Health Organization; $\mathrm{HAI}=$ Health Action International; INN = International Nonproprietary Name.

${ }^{c}$ Based on September 2005 exchange rate of US\$1 per 3.32 Peruvian nuevos soles. sale prices gathered by IMS Health during the same time period. Results are presented in Figure 3, with the diagonal line representing where observations would lie if the WHO/HAI retail prices and IMS wholesale prices were identical. In general, the WHO/HAI prices track IMS prices consistently above the diagonal, as would be expected after retailer markups. The 10 products with an IMS wholesale price > US\$ 0.25 per unit had an average retail markup of $37 \%$ (median $35 \%$ ) over the wholesale price. However, the 17 products at the lower end of the price spectrum appeared to have much larger markups, averaging $533 \%$ (median 284\%). For the 10 higherpriced ACE inhibitors, the correlation between IMS and WHO/HAI prices was nearly perfect (0.98), whereas the 17 lower-priced products had only a weak correlation (0.13).

\section{DISCUSSION}

This validation study found that availability and prices of medicines generally did not differ by degree of geographic remoteness from Lima or distance of private pharmacies from public health facilities. This suggests that the standard WHO/HAI sample of outlets, which is geographically limited for considerations of research cost and convenience, would be sufficient in a country with a distribution system like Peru's. However, the most recent WHO/HAI manual (1) recommends sampling in six rather than four regions to address the common problem of low medicine availability and to ensure sufficient price data for robust analysis.

Data on the expanded classes of ACE inhibitors, ulcer treatments, and oral diabetes medications demonstrated that the two standard WHO/HAI price measures-median originator brand and LPG-adequately summarize the range of market prices for the medicines targeted by the survey. Although the standard methodology cannot characterize the full distribution of market prices for each medicine, these distributions in Peru had a typical, skewed pattern that could be roughly inferred from the originator brand and LPG measures.

The availability and range of equivalent products were much higher for core list medicines than most alternatives. The wide availability of targeted medicines is a deliberate design feature of the 
FIGURE 2. Median $\operatorname{cost}^{\mathrm{a}}$ of 30 days' treatment of chronic illness through private retail pharmacies, within the three expanded therapeutic classes, by market category, WHO/HAI Medicine Prices and Availability survey validation, Peru, $2005^{\mathrm{b}}$

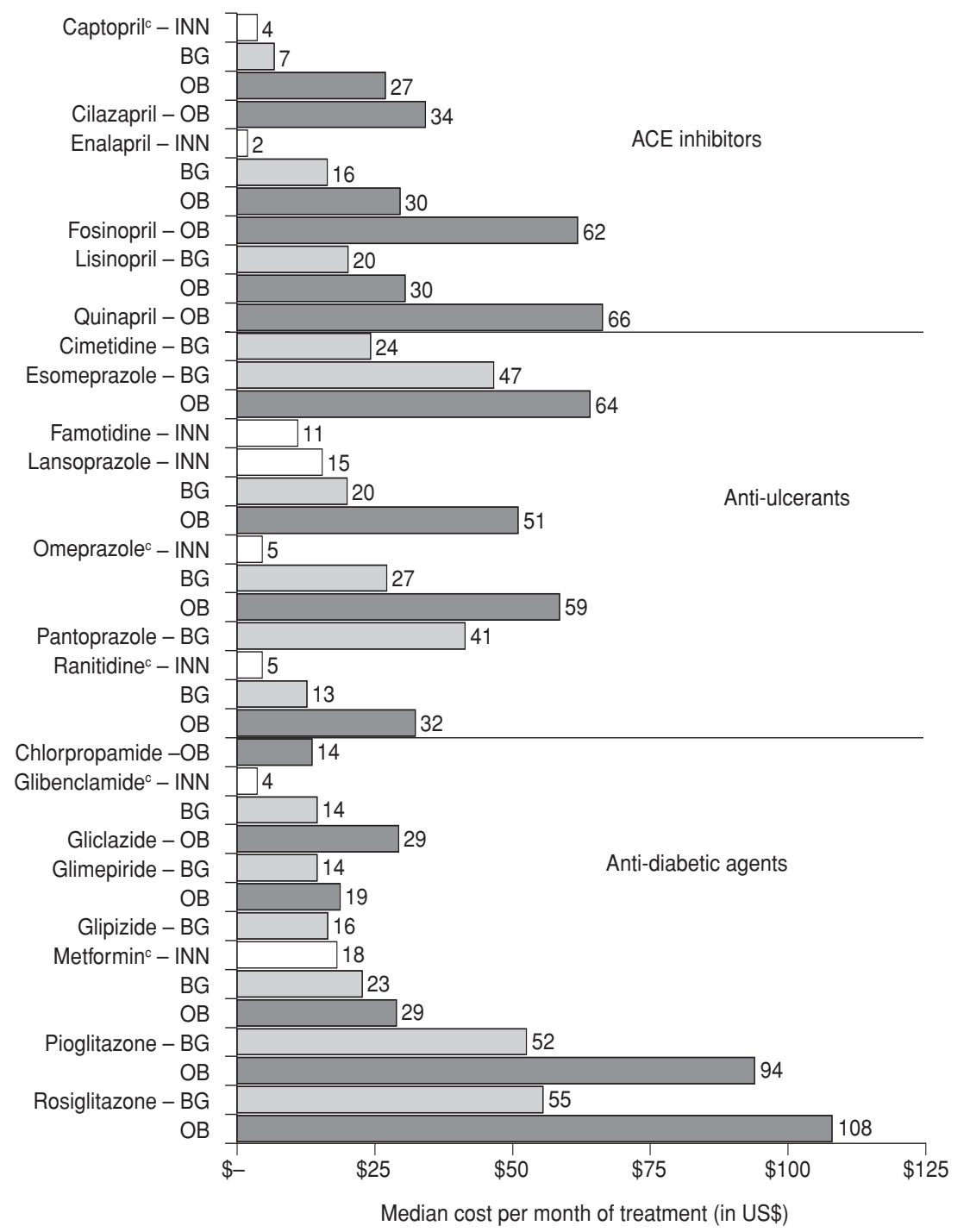

a Treatment costs are based on WHO DDDs and expressed in U.S. dollars (as per September 2005 exchange rate of US $\$ 1$ per 3.32 Peruvian nuevos soles). Affordability is gauged based on the minimum monthly government worker's wage, which at the time of the survey was 460 nuevos soles or US\$ 139).

${ }^{\mathrm{b}} \mathrm{ACE}=$ angiotensin-converting enzyme; INN = International Nonproprietary Name generic; $\mathrm{BG}=$ branded generic; $\mathrm{OB}=$ originator brand; $\mathrm{WHO}=$ World Health Organization; $\mathrm{HAI}=$ Health Action International; $\mathrm{DDD}=$ defined daily doses (number of tablets typically prescribed for one day of use) (16).

${ }^{c} \mathrm{WHO} / \mathrm{HAl}$ core list medicine in 2005.

WHO/HAI survey, as this increases the frequency of observed prices, the range of possible analyses, and the reliability of estimates. Furthermore, commonly used medicines are more likely to have easily available international reference prices.

The data from Peru indicate that certain characteristics of the core list medicines may not be representative of their therapeutic classes or of the overall mar- ket. Core list medicines tend to have been on the market longer and have fewer patent protections and greater generic competition. As a result, these medicines may have lower generic treatment costs and higher brand premium ratios than less widely used therapeutic alternatives. Thus, caution should be used in generalizing survey findings on treatment affordability to newer products. Nevertheless, commonly used medicines represent a high share of the consumption within their therapeutic classes, particularly among lower socioeconomic groups.

At present, the WHO/HAI methodology only measures market competition indirectly, through the availability and median prices of the originator brand and LPG competitors. A count (without prices) of the additional product versions of a medicine stocked in each outlet could be added to the survey to assess this dimension. It would be informative to examine generic competition in other countries or within additional therapeutic classes to complement the findings from Peru.

Within one therapeutic class, the Peru survey found that median retail prices bore a direct relationship to average wholesale prices determined independently by IMS. However, retailer markups could not be neatly characterized; on higher-priced products, markups under $50 \%$ were typical, while lower-priced products had much higher percentage markups, with greater variation. These findings are consistent with case studies describing the complete chain of markups on three individual medicines (14), which found retailer markups of $14 \%, 50 \%$, and $70 \%$ in Peru's private sector, with the smallest on an originator brand product and the largest on a generic. They are also consistent with the finding in Peru (15) that there is greater variability in prices across outlets for individual INN generic products than for individual branded generic products. Retailers may sense latitude to add higher markups to lowpriced products, or they may aim for a fixed per-tablet markup, which translates into a larger percentage markup on lower-priced medicines. Large variations in product price among retail outlets are striking in Peru (15) and in many other countries covered by the WHO/HAI surveys, and deserve closer investigation.

This validation study had several limitations. For example, the findings may not be generalizable to other countries with pharmaceutical markets and policy structures that differ markedly from Peru's, and, as noted above, the standard survey list of medicines may not be representative of all medicines marketed in Peru. In addition, the three expanded therapeutic classes of medicines were all used to treat chronic conditions and included only a small number of chemical entities, which were not perfect clinical 
FIGURE 3. Comparison of IMS Health ${ }^{\mathrm{a}}$ average wholesale prices and World Health Organization/Health Action International median retail patient prices for 27 specific angiotensin-converting enzyme (ACE) inhibitor products in Peru, ${ }^{\mathrm{b}}$ WHO/HAI Medicine Prices and Availability survey validation, 2005

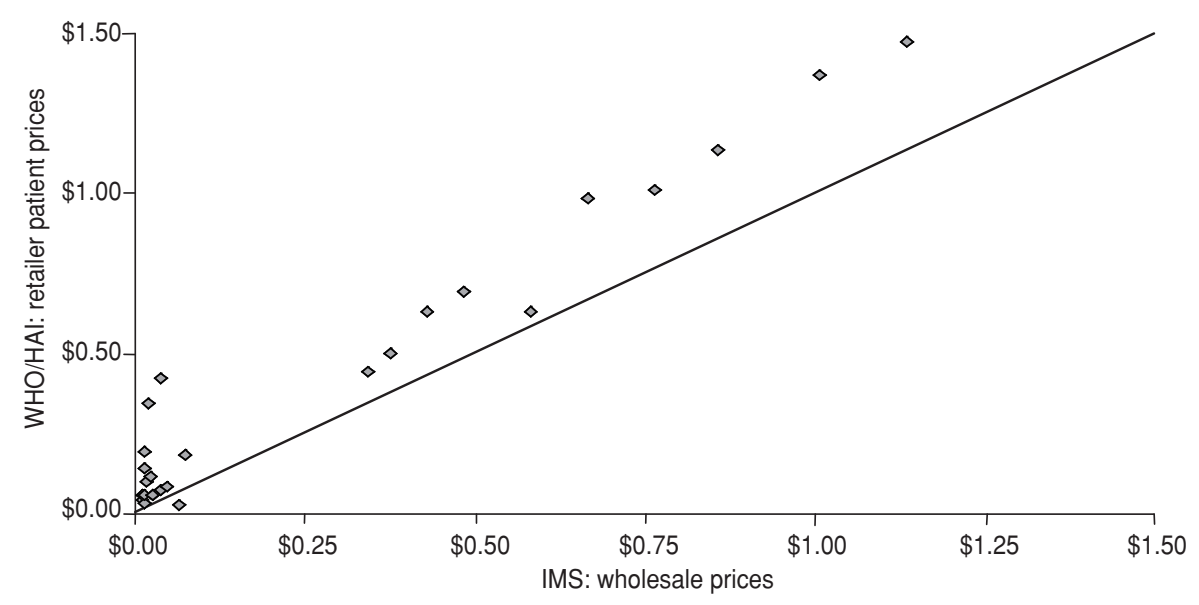

a Leading global supplier of pharmaceutical sales data.

${ }^{b}$ In U.S. dollars per unit (based on September 2005 exchange rate of US $\$ 1$ per 3.32 Peruvian nuevos soles).

substitutes, and therefore may not be representative of all medication classes.

The validation exercise found no evidence to suggest serious bias in the standard WHO/HAI survey design. The WHO/HAI price estimates reflect the range of market prices for different versions of the targeted medicines, which appear to be, as intended, among the most widely available and marketed products. Comparisons with independent wholesale data support the validity of retail prices gathered in the survey. Based on these results, $\mathrm{WHO} / \mathrm{HAI}$ Medicine Prices and Availability survey data can and should play an important role in advocacy for rational pharmaceutical policies in low-to-middle income countries.

Acknowledgments. The authors thank Roberto López, Sofia Salas, Elizabeth Bellido, and other members of the Peru survey team for their efforts. They also thank Alexandra Cameron of WHO for providing input into an early draft, and the many advisors to the WHO/HAI Project on Medicine Prices and Availability who have helped develop and refine its methods and devise strategies for validation. Financial support for the WHO/HAI project was provided by the Netherlands Ministry of Foreign Affairs; The Rockefeller Foundation; Swedish International Development Cooperation Agency; Department for International Development, UK; European Commission Directorate General Development and Relations with African, Caribbean and Pacific States; Open Society Institute; and Finnish International Development Agency.

\section{REFERENCES}

1. World Health Organization; Health Action International. Measuring medicine prices, availability, affordability and price components [Internet]. 2nd ed. Geneva: WHO/HAI; 2008 [cited 2009 Jun 5]. Available from: http://www.haiweb.org/medicineprices/ manual/documents.html.

2. Health Action International [Internet]. Amsterdam: HAI; c2009 [cited 2009 Jun 5]. Medicine prices, availability, affordability \& price components [about 11 screens]. Available from: http://www.haiweb.org/medicineprices/.

3. Cameron A, Ewen M, Ross-Degnan D, Ball D, Laing R. Medicine prices, availability, and affordability in 36 developing and middleincome countries: a secondary analysis. Lancet. 2009; 373(9659):240-9. Epub 2008 Nov 29.

4. Health Action International. Medicine pricing matters [Internet]. Amsterdam: HAI; 2008 [cited 2009 Jun 5]. No. 4, Dec 2008. Available from: http://www.haiweb.org/medicineprices/ 28012009/MPM-Issue-4.pdf.

5. United Nations Millennium Development Goals Gap Task Force. Access to affordable essential medicines. In: Strengthening the global partnership for development in a time of crisis. MDG Gap Task Force report 2009 [Internet]. New York: UN; 2009 [cited 2009 Nov 14]. p. 49-62. Available from: http://
www.un.org/millenniumgoals/pdf/MDG_ Gap_\%20Task_Force_\%20Report_2009.pdf.

6. MacIntyre K. Rapid assessment and sample surveys: trade-offs in precision and cost. Health Policy Plan. 1999;14(4):363-73.

7. Frerichs RR, Shaheen MA. Small-community-based surveys. Annu Rev Public Health. 2001;22:231-47.

8. Management Sciences for Health. International drug price indicator guide [Internet]. Cambridge (MA): MSH; 2009 [cited 2009 Jun 5]. Available from: http://erc.msh.org/main page.cfm file $=1.0 . \mathrm{htm} \&$ module $=\mathrm{DMP} \&$ language $=$ English .

9. World Bank. Selected indicators. In: World development report 2008: agriculture for development [Internet]. Washington: World Bank; 2007 [cited 2009 Jun 5]. Available from: http: / / siteresources.worldbank.org/ INTWDR2008 / Resources / 2795087 1192112387976/WDR08_24_SWDI.pdf.

10. IMSHealth.com [Internet]. Norwalk (CT): IMS Health; c2009 [cited 2009 Jun 5]. Available from: http://www.imshealth.com/portal/site/imshealth.

11. Danzon PM, Kim JD. International price comparisons for pharmaceuticals: measurement and policy issues. Pharmacoeconomics. 1998;14 Suppl 1;115-28.
12. Campbell MJ, Gardner MJ. Calculating confidence intervals for some non-parametric analyses. Br Med J. 1988;296(6634):1454-6.

13. Sunat.gob.pe [Internet]. Lima: Superintendencia Nacional de Administración Tributaria; c1997-2009 [cited 2009 Nov 14]. Available from: http:/ / www.sunat.gob.pe.

14. Health Action International, Latin American Coordination Office. Availability, affordability and price components in Peru [Internet]. Amsterdam: HAI; 2007 [cited 2009 Jun 5]. Available from: http://www.haiweb.org/ medicineprices/surveys/200509PE/sdocs/ survey_report.pdf.

15. World Health Organization/Health Action International Project on Medicine Prices and Availability. Peru validation study report [Internet]. Amsterdam: HAI; 2006 [cited 2009 Jun 5]. Available from: http://www.hai web.org/medicineprices/news/22012009/ PeruValidationReportfinal.pdf.

16. World Health Organization Collaborating Centre for Drug Statistics Methodology. ATC/DDD Index 2009. Oslo: WHO CCDSM; 2009 [cited 2009 Jun 5].

Manuscript received on 25 August 2009. Revised version accepted for publication on 24 December 2009. 
RESUMEN Objetivos. Evaluar la posibilidad de sesgo debido a la limitación de la lista de referencia y del muestreo geográfico de la encuesta de precios y disponibilidad de medicamentos de la Organización Mundial de la Salud/Health Action International

Determinación de los precios de los medicamentos en Perú: validación de aspectos fundamentales del método de encuesta de la OMS/HAI

Palabras clave
(OMS/HAI) usada en más de 70 muestras de encuestas rápidas desde el 2001.

Métodos. En el año 2005, se realizó una encuesta en Perú, con una muestra ampliada de puntos de venta de medicamento, incluso en zonas remotas. Se recogieron datos integrales acerca de los medicamentos de tres clases terapéuticas, con el fin de evaluar la idoneidad de la lista de referencia de medicamentos de la OMS/HAI y el énfasis únicamente en dos versiones del producto. Las medianas de los precios al por menor de la OMS/HAI se compararon con el promedio de precios al por mayor del proveedor de datos mundiales de ventas farmacéuticas IMS Health.

Resultados. No se observó ninguna diferencia significativa en la disponibilidad general ni en los precios de los medicamentos de la lista de referencia por localización de venta al por menor. La encuesta integral de los inhibidores de la enzima convertidora de la angiotensina, los antidiabéticos y los productos antiulcerosos reveló que algunos tratamientos que no están en la lista destinataria eran más caros para los pacientes y era más probable que no estuvieran a la venta, sobre todo en las regiones remotas. Los precios al por menor de la OMS/HAI y los precios al por mayor de IMS presentaron una correlación intensa en el caso de los productos de precio más alto, y la correlación fue débil en el caso de los productos de precio más bajo (que tuvieron márgenes de beneficio calculados más altos para el minorista).

Conclusiones. El método de la encuesta de la OMS/HAI logra un equilibrio adecuado entre los costos de investigación moderados y la información óptima para la política. El énfasis en los medicamentos de uso frecuente produce unos resultados válidos y suficientes. Los encuestadores de otros lugares deberían tener en cuenta los límites de los datos de la encuesta, así como las circunstancias locales, como la escasez, que puede requerir mayores esfuerzos en el campo.

Precio de medicamento; estudios de validación; encuestas de atención de la salud; farmacias; muestreo; Perú. 